\title{
ENERGY BALANCE OF RURAL ECOSYSTEMS IN INDIA
}

\author{
Abha Chhabra $^{\text {a }}$, V. Madhava Rao ${ }^{\mathrm{b}}$, R.R. Hermon ${ }^{\mathrm{b}}$, Amit Garg $^{\mathrm{c}}$, Tirthankar Nag ${ }^{\mathrm{c}}$, N. Bhaskara Rao ${ }^{\mathrm{b}}$, A. Sharma ${ }^{\mathrm{c}}$ and J.S Parihar $^{\mathrm{a}}$ \\ ${ }^{a}$ Earth, Ocean, Atmosphere, Planetary Sciences and Applications Area, Space Applications Centre, ISRO, Ahmedabad -380015 \\ ${ }^{\mathrm{b}}$ Centre on Geoinformatics Applications in Rural Development, National Institute of Rural Development, Hyderabad- 500030 \\ ${ }^{\mathrm{c}}$ Public Systems Group, Indian Institute of Management, Ahmedabad- 380015
}

KEY WORDS: Rural ecosystem, Agroclimatic regions, Anthropogenic energy flows, Field data, Remote Sensing and GIS, Rural Energy Balance Model, Net Energy Balance

\begin{abstract}
:
India is predominantly an agricultural and rural country. Across the country, the villages vary in geographical location, area, human and livestock population, availability of resources, agricultural practices, livelihood patterns etc. This study presents an estimation of net energy balance resulting from primary production vis-a-vis energy consumption through various components in a 'Rural Ecosystem'. Seven sites located in different agroclimatic regions of India were studied. An end use energy accounting 'Rural Energy Balance Model' is developed for input-output analysis of various energy flows of production, consumption, import and export through various components of crop, trees outside forest plantations, livestock, rural households, industry or trade within the village system boundary. An integrated approach using field, ancillary, GIS and high resolution IRS-P6 Resourcesat-2 LISS IV data is adopted for generation of various model inputs. The primary and secondary field data collection of various energy uses at household and village level were carried out using structured schedules and questionnaires. High resolution multi-temporal Resourcesat-2 LISS IV data (2013-14) was used for generating landuse/landcover maps and estimation of above-ground Trees Outside Forests phytomass. The model inputs were converted to energy equivalents using country-specific energy conversion factors. A comprehensive geotagged database of sampled households and available resources at each study site was also developed in ArcGIS framework. Across the study sites, the estimated net energy balance ranged from -18.8 Terra Joules (TJ) in a high energy consuming Hodka village, Gujarat to 224.7 TJ in an agriculture, aquaculture and plantation intensive Kollaparru village, Andhra Pradesh. The results indicate that the net energy balance of a Rural Ecosystem is largely driven by primary production through crops and natural vegetation. This study provides a significant insight to policy relevant recommendations for Energy Sustainable Rural India.
\end{abstract}

\section{INTRODUCTION}

India is predominantly an agricultural and rural country with majority of its people living in the villages. The recent census (Census, 2011) has estimated country's population at 1210 million, of which the rural population stands at 833.1 million (68.8\%) with an increase of 90.47 million during the last decade (2001-2011). There are 6,40867 villages in India, an increase of 2279 villages during the last decade. The Indian villages vary in size and other characteristics (Singh et al., 2008). Some villages are very small, having less than 50 residents, to large villages with more than 10,000 residents. The current population growth rate in rural areas is estimated at $12.18 \%$. Across the country, the villages vary in population density, geographical location, availability of resources, agricultural practices, tree plantations, livelihood patterns etc. The energy use in the rural areas largely depends on the population size, amount of arable land, cropping practices, crop production, level of agricultural mechanization, livestock keeping, food habits, domestic energy needs, availability of resources and economic conditions of the population. Rural ecosystem is a thrust area of research for understanding its 'energy balance' and 'carbon footprints'.

Rural areas offer significant environmental contributions through primary energy production by vegetation in form of crop biomass and tree phytomass. Trees outside forests, which include trees on agricultural lands, along canals, roads, homestead plantations etc. play multifunctional roles by providing a wide range of goods and services, particularly to rural livelihoods and wood-based industries, besides various ecological benefits. Wood is an energy source for cooking and heating in rural households. Livestock keeping has been an integral part of rural livelihoods in India as animal energy is a renewable and sustainable source of energy. Livestock convert energy stored in biomass (fodder, crop residues etc.) unsuitable for human consumption to useful products in form of milk, meat, eggs, wool etc.

The energy balance of rural areas is rarely assessed at the national scale. Only few scattered point studies are available. Pandya and Pedhadiya (1993) presented an energy analysis of a semi-arid village ecosystem in Gujarat and reported that village is self-sustaining due to surplus available energy. This study did not include energy production through tree plantations and energy flows through various subsystems were also limited. Hippel et al. (2001) presented a study of Rural Energy Survey in Unhari village of The Democratic People's Republic of Korea to bring out more reliable, renewable-resource-based electricity supplies and energy efficiency measures to the village. Ozkan et al. (2004) reported the Energy Input-Output analysis in Turkish agriculture. Ramachandra et al. (2000) made a comparative analysis of village level domestic energy consumption patterns across coastal, interior, hilly and plain zones considering regional and seasonal variations in Uttara Kannada district, Karnataka. Chandra et al. (2011) made an analysis of resource input-output energy in traditional crop production in Central Himalayas, India. Their study indicated that the total energy inputs and outputs are higher for irrigated agriculture as compared to rainfed system. A village level study reported the present scenario of domestic energy consumption

* Corresponding author e-mail: abha@sac.isro.gov.in 
and potential of Bioenergy resources to meet the energy demands (Ramachandra et al., 2014).

In a vast country like India, it is important to understand and quantify the pathways of anthropogenic energy flows in varied Rural Ecosystems in different agroclimatic regions of the country. Therefore, this study was undertaken to present an assessment of net energy balance resulting from primary production vis-a-vis energy consumption, imports and exports through various components within the village boundary in diverse rural ecosystems. The major objectives of the study are:

- Quantitative estimation of primary energy production by different vegetation types at village level.

- Quantitative estimation of energy consumption, import and export through crops, livestock, tree plantations and human livelihood at village level.

- Development of an Energy flow model and assessment of net energy balance of Rural Ecosystem.

\section{MATERIAL AND METHODS}

\subsection{Study area and Data Used}

Village is the basic spatial unit for this study. Seven study sites located in different agroclimatic regions of India have been studied. These include: Ralegan Siddhi, (Taluka Parner, District Ahmedanagar, Maharashtra) in Western Plateau and Hills Region, Macchiwara Kham, (Taluka Macchiwara, District Ludhiana, Punjab) in Trans Gangetic Plain Region, Sunderdev (Taluka Khalwa, District Khandwa, Madhya Pradesh in Western Plateau and Hills Region, Hodka (Taluka Bhuj, District Kachchh, Gujarat) in Gujarat Plains and Hills Region), Keralapuram (District North Andaman, Andaman \& Nicobar Islands) in Islands Region, Kollaparru (Taluka Akividu, District West Godavari, Andhra Pradesh) in East Coast Plains and Hills Region, Phura (Taluka Tuipang, District Saiha, Mizoram) in Eastern Himalayan Region (Figure 1).

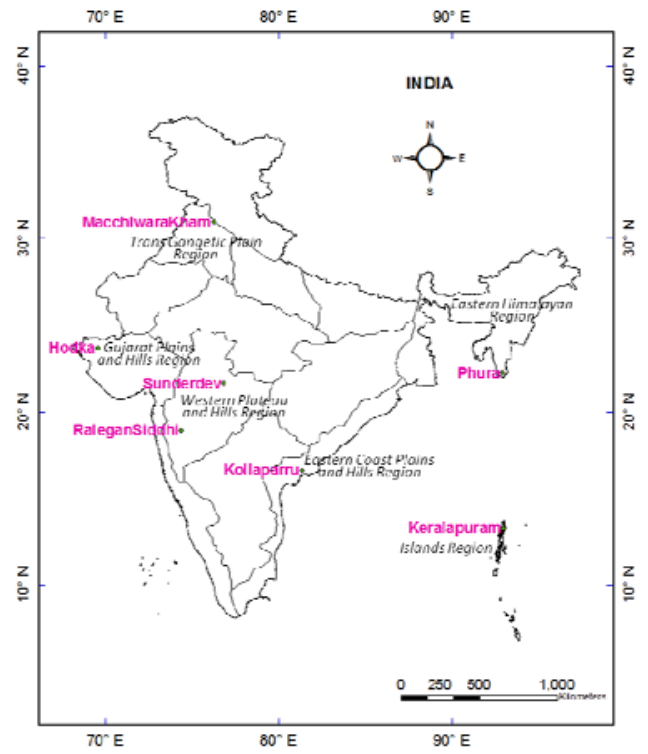

Figure 1: Study sites located in different agroclimatic regions (italics) of India
The study utilized ancillary data, remote sensing and GIS data and extensive field data. The primary data of population, occupation, social and economic status, agriculture, aquaculture, livestock species and their produce, trees outside forests, food basket, fossil fuel, biofuel consumption, industry inputs and outputs at household level and secondary data at village level were collected through field survey at each of the study site. The country-specific energy conversion factors were collected through a detailed literature survey. The primary data of availability, need, perception and priorities of various renewable and non-renewable energy resources were also collected through Participatory Rural Appraisal during the field surveys. High resolution multi-temporal IRS-P6 Resourcesat-2 LISS IV Full multi-spectral data $(5.8 \mathrm{~m})$ were used to derive landuse/landcover classification map of the study sites and estimation of above-ground Trees Outside Forests phytomass using an integrated Remote Sensing and GIS based spatial approach with the supplement of field measurements. The satellite data used for the study is listed in Table 1:

\begin{tabular}{|l|l|l|}
\hline $\begin{array}{c}\text { S. } \\
\text { No. }\end{array}$ & \multicolumn{1}{|c|}{ Study site } & \multicolumn{1}{|c|}{ Resourcesat-2 LISS IV data } \\
\hline 1. & $\begin{array}{l}\text { Ralegan Siddhi, } \\
\text { Maharashtra }\end{array}$ & $\begin{array}{l}\text { 20 October 2011, 25 December } \\
\text { 2012 and 31 March 2013 }\end{array}$ \\
\hline 2. & $\begin{array}{l}\text { Macchiwara Kham, } \\
\text { Ludhiana }\end{array}$ & $\begin{array}{l}\text { 04 October 2012, 01 February } \\
\text { 2013 and 01 June 2013 }\end{array}$ \\
\hline 3. & $\begin{array}{l}\text { Sunderdev, } \\
\text { Madhya Pradesh }\end{array}$ & $\begin{array}{l}\text { 12 November 2012, 05 April } \\
\text { 2013, 01 December 2013 }\end{array}$ \\
\hline 4. & Hodka, Gujarat & $\begin{array}{l}\text { 05 February, 2013, 12 May } \\
\text { 2013, and 20 November 2013 }\end{array}$ \\
\hline 5. & Keralapuram, ANI & $\begin{array}{l}12 \text { November 2012, 05 April } \\
\text { 2013 and 01 December 2013 }\end{array}$ \\
\hline 6. & $\begin{array}{l}\text { Kollaparru, Andhra } \\
\text { Pradesh }\end{array}$ & $\begin{array}{l}\text { Nov 2012, May 2013 and 17 } \\
\text { Feb, 2014 }\end{array}$ \\
\hline 7. & Phura, Mizoram & $\begin{array}{l}\text { 08 April 2013, 17 October, } \\
\text { 2013 and 21 January, 2014 }\end{array}$ \\
\hline
\end{tabular}

Table 1: Multi-temporal satellite data used in the study

\subsection{Approach}

A conceptual framework was developed for detailed estimation of different pathways of anthropogenic energy flows through various subsystems of crop, livestock keeping (including poultry) and aquaculture (wherever applicable), trees outside forest plantations, rural households, industry or trade within the village system boundary (Figure 2).

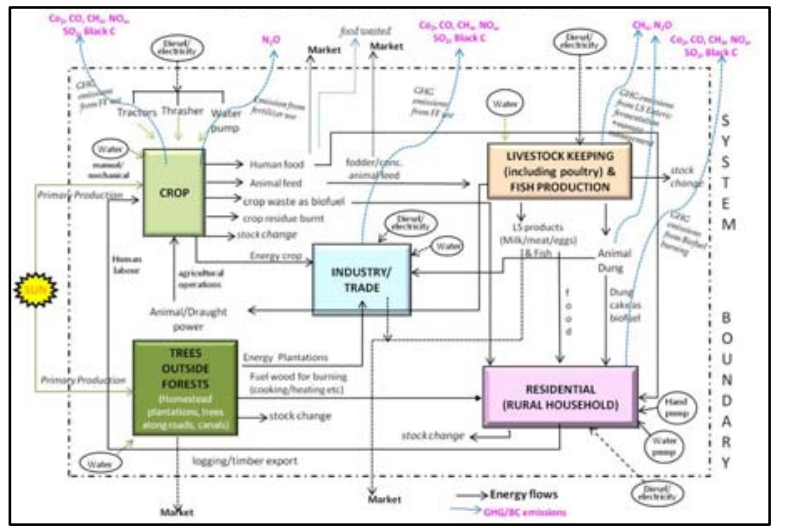

Figure 2: Basic conceptual framework of pathways of Energy Flows in a Rural Ecosystem 
2.2.1 Sampling Methodology: A stratified random sampling approach based on primary occupation of rural households was adopted for field data collection of 100 households using structured schedules. The secondary village level data collection was based on detailed questionnaires developed for this study. An example of sampling methodology used for Ralegan Siddhi village is shown in Figure 3.

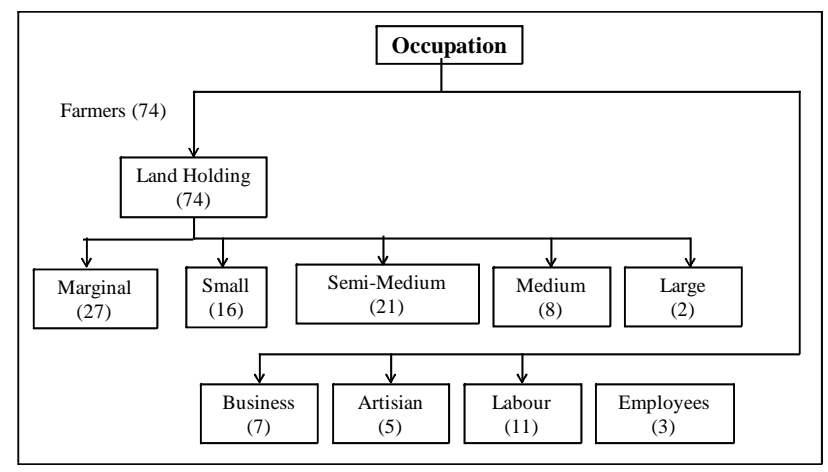

Figure 3: An example of sampling methodology for household data collection (number in parenthesis indicate sampled households)

Farmers were further classified into marginal, small, semimedium, medium and large on the basis of their landholding size (ICAR based classification). The social and economic status of households was included during household sampling. The village level data was collected from Panchayat office, Gramsewak office, Talati Revenue office, Black Development office, Social Forestry office, Veterinary office and Electricity office at Taluka or block level (Figure 4). The Participatory Rural Appraisal (PRA) at the study sites was carried out using various tools of Social mapping, Resource mapping, Transect walk, Focussed discussion, Preference Ranking, Seasonal diagrams and Matrix ranking.

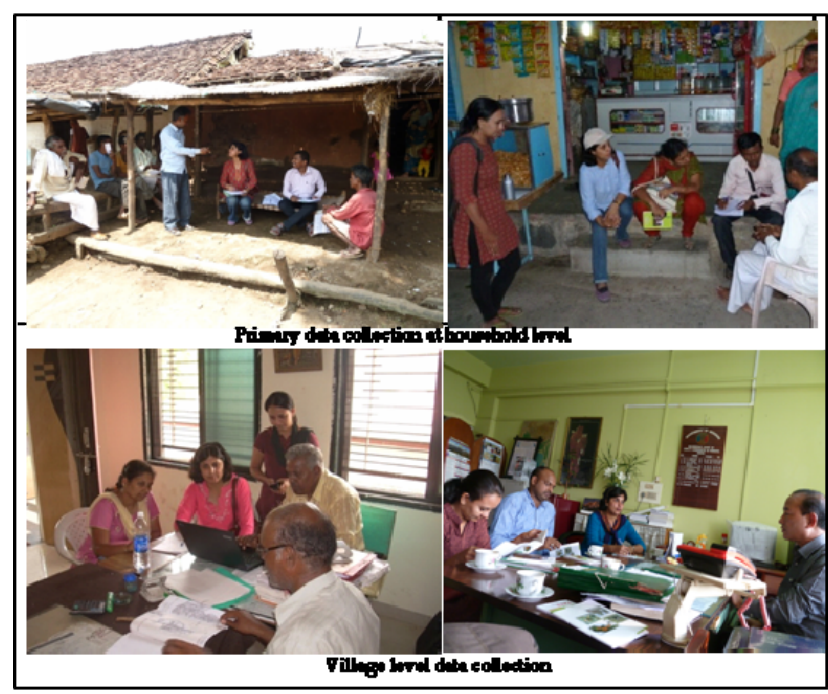

Figure 4: Field data collection at the study site

The field measurements of Trees Outside Forests (TOFs) within the village boundary were collected using a random stratified sampling deign for linear, block and scattered strata as described by Forest Survey of India for TOF inventory (Rawat et al., 2005). The stratified random sampling scheme has been designed and applied to collect and characterize the data related to TOF. The stratified random sampling design was preferred because it captures each and individual TOF characteristic in the sample and it is likely to be more representative of the each TOF population within individual TOF strata rather than a random sample of the same size. In the field, the nondestructive approach of phytomass estimation was adopted. The dimensions of the sampling plot were taken $50 \mathrm{~m} \times 20 \mathrm{~m}$ for linear trees along the roads and canal, $32 \times 32 \mathrm{~m}$ for the block strata and $50 \times 50 \mathrm{~m}$ for scattered strata. The detailed field measurements at sample plots included enumeration of trees, identification of tree species, tree height using altimeter, Girth at Breast Height using measuring tape and location of sample plots using a handheld GPS. A pictoral representation of field measurements of TOFs is shown in the figure 5.

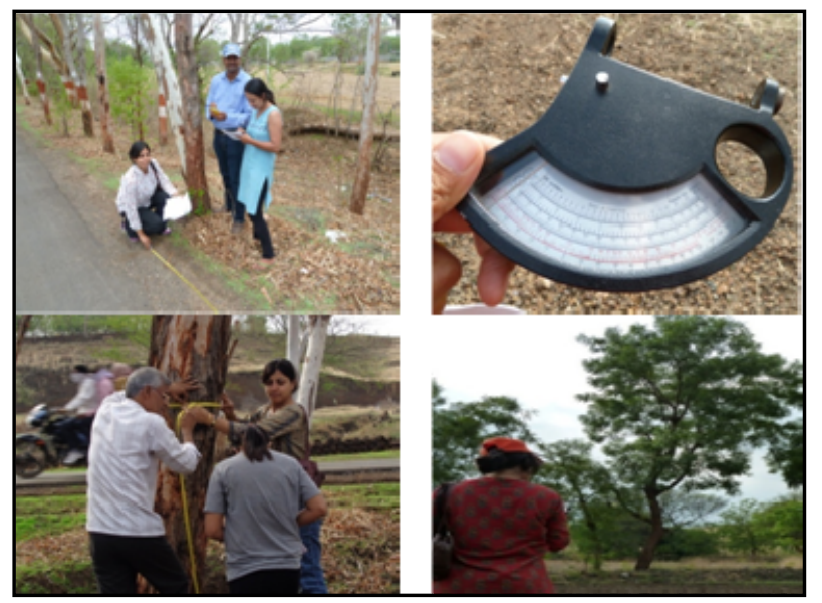

Figure 5: Field measurements of Trees Outside Forests

2.2.2 Database Preparation: The detailed household and village level statistical databases for each of the seven study sites were prepared using the collected field data. Site-wise sample plot field data on Trees Outside Forests were organized in a spreadsheet and processed in a database environment. The wood volume of individual trees was estimated using speciesspecific volume equations given by Forest Research Institute, Dehradun (FRI, 1996). General volume equations were applied for few tree species for which specific equations were not available. The estimated wood volume was multiplied by species specific gravity of wood to calculate tree phytomass. The phytomass of the individual tree was added to find out total TOF phytomass for each sample plot.

The remote sensing database for each of the study site was prepared using cloud-free multi-temporal Resourcesat-2 LISS IV data. The administrative boundary coverage of each of the study village as obtained from Survey of India database was used to subset the LISS-IV images. In case of Macchiwara kham village of Punjab, current village boundary was not available. The village boundary was extracted using the village revenue map and georeferenced using ground control points collected during the field visit. The Hodka village of Gujarat is not a revenue village and falls under joint panchayat system. The administrative boundary coverage is not available, therefore village boundary was considered based on the ground truth knowledge and available literature. The preprocessing of procured georeferenced data involved atmospheric correction using SACRS2 tool for LISS-IV data (Pandya et al., 2013). LISS-IV image were resampled from $5.8 \mathrm{~m}$ pixel to $6 \mathrm{~m}$ pixel to get the better approximation of the results while computing area under each landuse landcover category. The image classification on multi-temporal dataset was attempted in 
ERDAS IMAGINE ver. 9.2 image processing software. The unsupervised ISODATA classification algorithm was applied. The spectral classes obtained were grouped into seven categories viz. built-up land, single crop, double crop, fallow land, scrub land, fallow land, plantation and water body. The three strata of block, linear and scattered trees outside forests were included under plantations category. The classified image was then visually analysed for editing and refinement for inclusion and omission of misclassified patches. The classified raster image was further converted into vector format for enabling GIS analysis of the layer. The area under each landuse/landcover category was estimated and landuse landcover maps were derived in ArcGIS ver. 9.2. The plantations category of the final classified map was then used for aboveground phytomass estimation based on an integrated methodology using remote sensing, GIS and field measurements of TOFs (Singh and Chand, 2012). The estimated phytomass was converted to carbon content using a coefficient of 0.5 (Brown et al., 1999). In case of arid grasslands at Hodka, grassland biomass density of Banni grasslands was used from literature (Patel et al., 2012). Coconut is the major tree plantation at Kollaparu village, Andhra Pradesh. The speciesspecific volume equation was not available, therefore biomass density of $143 \mathrm{t} / \mathrm{ha}$ was adopted from literature (Sundarapandian et al., 2013). An integrated natural and human resources survey and mapping was carried out at each of the study site. The Village GIS framework was developed in ArcGIS ver. 10.1 using the GPS locations and details of all the sampled households, available resources and field photographs collected during the field visit.

2.2.3 Rural Energy balance model development and inputs generation: An End use energy accounting 'Rural Energy balance Model' has been developed under this study to provide a complete assessment of Net Energy Balance (NEB) of a Rural Ecosystem. The model has been developed on MSAccess platform with a user friendly interface and ability to handle large volume of data (Figure 6).

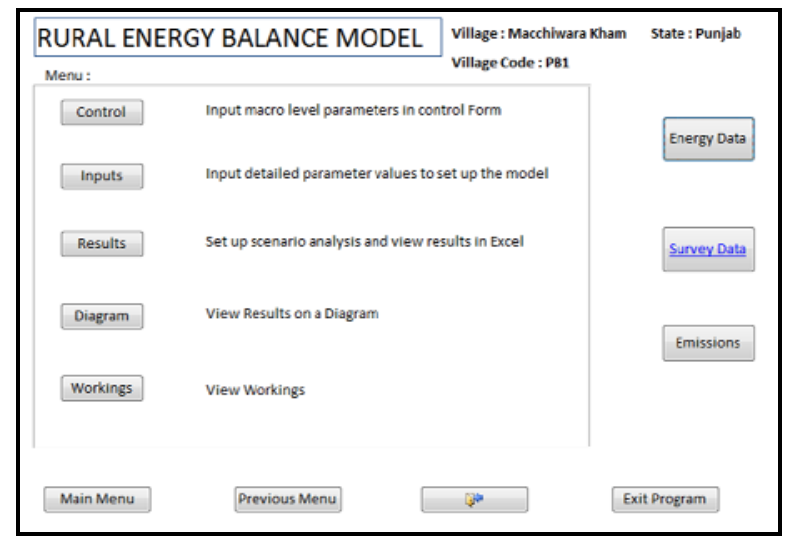

Figure 6: An example to illustrate the user interface of Rural Energy Balance Model

The model is based on the principles of pathways of energy flows across the various producers and consumers, imports and exports of energy within a village system boundary. The model takes inputs for five basic subsystems of crop, livestock, residential, industry/trade and trees outside forests. The model inputs include sample mean, minimum and maximum for each unit in the analysis based on the household database projected over the village population using the statistical analysis software SPSS ver. 19. The crop biomass inputs were computed using economic yield, moisture fraction and conversion factors for each crop (Dadhwal et al., 1994, 1996). The model takes the inputs and generates the final energy output values based on the various calculations and mathematical formulations, making the use of conversion factors fed into it. The model allows the user selectable analysis based on the three pivots (social status, occupation and economic background) and combinations therefore. The control parameters and energy references are also the basis of scenario analysis for various cases, and also include the provision for uncertainty analysis. The pivot weights may be used to project the values for each of the inputs and outputs for all the sectors. The details of the model and compilation of energy conversion factors used in the study are given by Nag et al., 2014 and Garg et al., 2014. The overall methodology of the study is illustrated in Figure 7. This inputoutput analysis is applied to characterize the energy balance of a Rural ecosystem that may be linked with policy design and implementation.

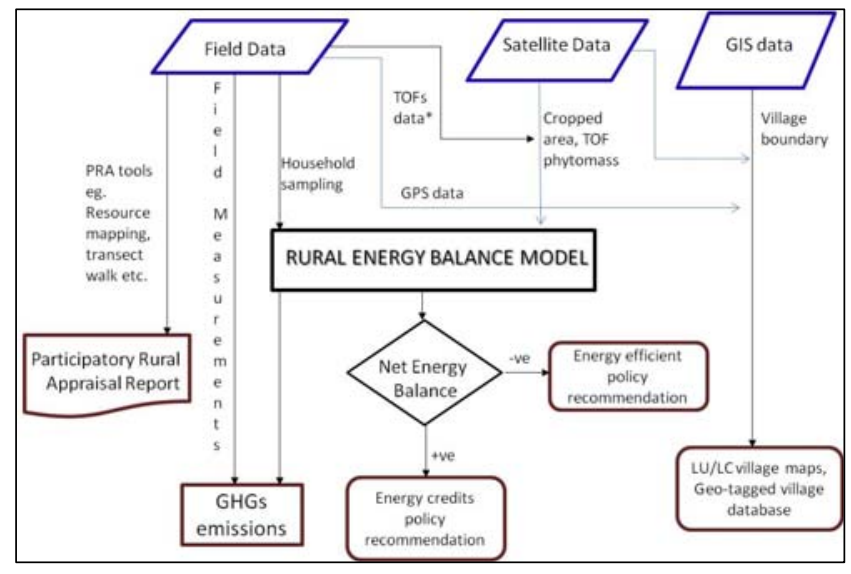

Figure 7: Flow diagram of the overall methodology of the study

\subsection{RESULTS AND DISCUSSION}

There is a large diversity in available energy resources, crop, livestock and human energy inputs across the seven study sites. The landuse/landcover maps derived from multi-temporal Resourcesat-2 LISS-IV data are shown in the figure 8. The energy flows in a village are mainly affected by agroclimatic conditions, human and livestock population, cropping practices and tree plantations. Across the study sites, the estimated net energy balance ranged from -18.8 Terra Joules (TJ) in a high energy consuming Hodka village, Gujarat to $224.7 \mathrm{TJ}$ in an agriculture, aquaculture and plantation intensive Kollaparru village, coastal Andhra Pradesh. The results indicate that the net energy balance of a Rural Ecosystem is largely driven by primary production through crops and natural vegetation. Hodka village lies in Banni grasslands area of Kuchchh, Gujarat and there is no crop production in this village. Due to arid climate, tree plantations are also limited to Acacia and Prosopis, which is largely cut down for charcoal making as an occupation and source of fuel for various cooking and heating purposes. Thus, energy production through natural vegetation is limited to arid grassland only. However, the energy consumption patterns were quite high. Livestock keeping is the one of the major occupation of residents of this village. The highest cattle population 1834 was observed at this village and characterised by Banni buffalo, a very high milk yielding breed of buffalo. 
The per capita milk production is 4.05 litres/day which is higher than state average of 3.85 litres/day (BAH statistics, 2013). Besides, due to its proximity to Rann of Kuchchh, in past few years Hodka has become a popular destination for tourists with availability of resorts and other commercial facilities. The electricity consumption was $394 \mathrm{kWH}$ per month per household as compared to only $4 \mathrm{kWH}$ per month per household at Sunderdev, a tribal village in M.P.

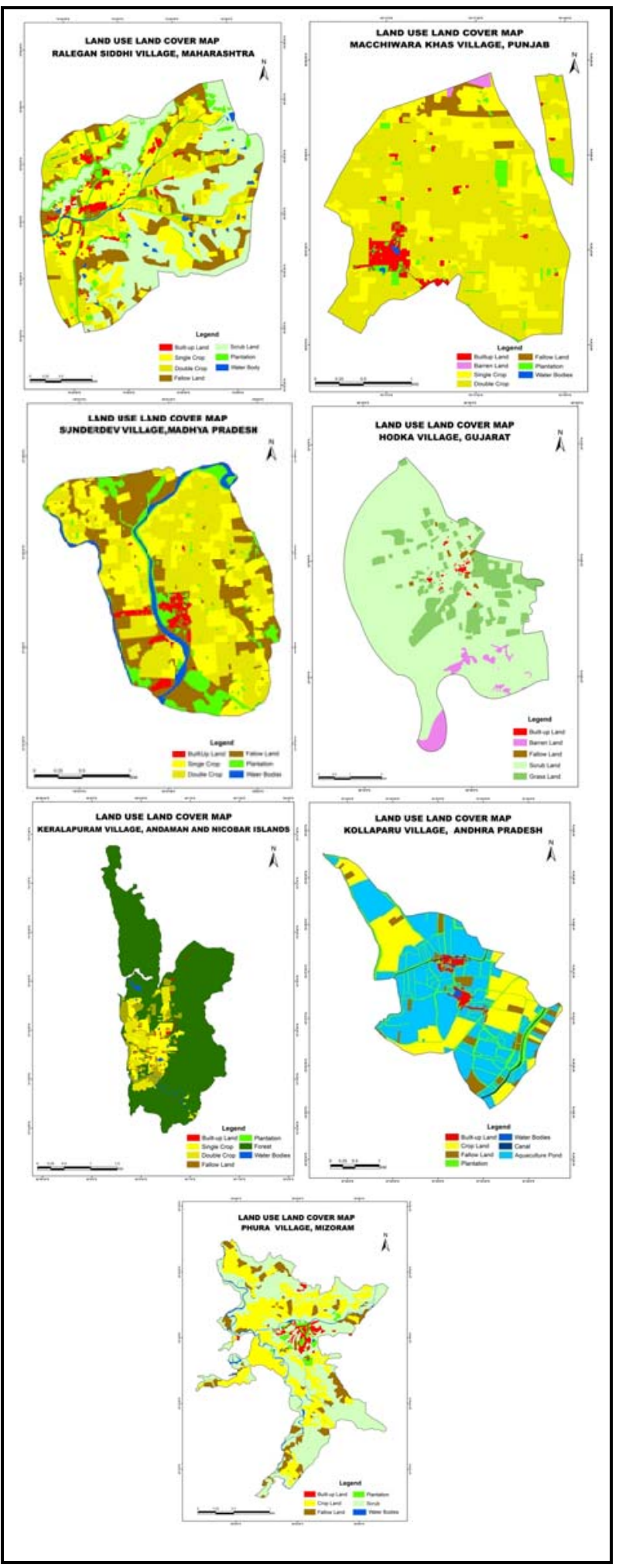

Figure 8: Landuse/land cover maps of all the seven study sites
The Kollaparru village in the coastal Andhra Pradesh is an agriculture, aquaculture intensive village with abundant coconut plantations. Paddy is the main crop and it is mostly rainfed. Among the aquaculture practices, fish and prawn farming are the major occupations. The energy inputs in form of feed and pesticides are largely imported into village boundary. However, the aquaculture produce is largely exported to the nearest town Bhimavaram, which is the aquaculture capital of the country. This village had higher energy production through crops and tree plantations against the energy consumption through electricity, fossil fuel or biofuel. The energy inputs from natural sources like sunlight and water have not been quantified in the current analysis. Therefore, trees subsystem in the REB model analysis indicates only energy production through tree phytomass.

The study results indicate that villages are generally energy positive, mainly driven by solar energy, converted into crop and tree biomass. The Rural households are generally energy negative, mainly due to availability of commercial energy in form of fossil-fuel derived electricity and use of biofuels. In Phura and Sunderdev villages, wood consumption was found to be very high (359 and $118 \mathrm{~kg}$ per month per household, respectively) for residential cooking and heating purposes. This is due to free availability of fuel wood resource from the surrounding forest area of village. Few model inputs viz. crop yield, human feed intake, livestock feed intake and milk produce were checked against benchmark district or state estimates for validation (NS0 2010, Agriculture Statistics, 2013). Estimated crop and tree biomass showed very high correlation with Net Energy Balance $(r=0.92)$ as compared to food energy intake by humans or livestock $(r=0.21$ and 0.42 , respectively). A summary of geographic area, Remote sensing derived crop area and area under plantations, human and livestock population and estimated net energy balance and per capita energy balance for all the study sites is given in Table 2 .

\begin{tabular}{|l|r|r|r|r|r|}
\hline Village & \multicolumn{1}{|c|}{$\begin{array}{c}\text { Geog } \\
\text { Area } \\
\text { (ha) }\end{array}$} & $\begin{array}{c}\text { Huma } \\
\text { n } \\
\text { Popul } \\
\text { ation }\end{array}$ & $\begin{array}{c}\text { Lives } \\
\text { tock } \\
\text { Popul } \\
\text { ation }\end{array}$ & $\begin{array}{c}\text { NEB } \\
\text { (TJ) }\end{array}$ & $\begin{array}{c}\text { Per } \\
\text { capita } \\
\text { EB }^{\$} \\
\text { (GJ) }\end{array}$ \\
\hline $\begin{array}{l}\text { Ralegan } \\
\text { Siddhi }\end{array}$ & 985.7 & 2317 & 1173 & 13.06 & 5.64 \\
\hline $\begin{array}{l}\text { Macchiwara } \\
\text { Kham }\end{array}$ & 398.2 & 1125 & 303 & 12.25 & 10.89 \\
\hline Sunderdev & 362.8 & 1664 & 680 & 20.86 & 12.53 \\
\hline Hodka & 3217.8 & 1500 & 1834 & -18.83 & -12.55 \\
\hline $\begin{array}{l}\text { Keralapura } \\
\text { m }\end{array}$ & 610.1 & 647 & 203 & 43.01 & 66.47 \\
\hline Kollaparu & 878.2 & 2199 & 442 & 224.68 & 102.17 \\
\hline Phura & 359.3 & 1377 & 386 & -13.19 & -9.57 \\
\hline
\end{tabular}

Net Energy Balance (TJ=Terra Joules $10^{12} \mathrm{~J}$ ), GJ = Giga Joules $10^{9} \mathrm{~J}$

Table 2: Estimated Net Energy Balance for the study sites

The uncertainty in these estimates may lie in the range of 18$20 \%$ arising from model inputs and energy conversion factors used in the study. The field data collected at household level is based on the recall knowledge of the residents which may introduce some errors. Although, the sample mean, maximum and minimum were generated and inputs from household database were projected to the village population, the model assume homogeneity within categories at the village level. This may or may not hold true for specific villages. Some assumptions like average rating of electrical appliances was 
considered same across all study sites due to lack of precise data. The model inputs generated through remote sensing based area and tree phytomass estimates might have introduced an error of about 8-10\%; as in few cases like Hodka and Macchiwara Kham villages SOI administrative boundary coverage were not available and derived based on field knowledge and cadastral map available with village resources. Also, for few tree plantations general volume equations and biomass density for grassland was adopted from literature. The imprecise accounting of fuel wood used by villagers and open grazing by livestock are other factors that might add uncertainties to the study estimates. Although, scenario analysis and estimation of Green Houses Gases emissions from various energy uses have been attempted within the framework of Rural Energy balance model, however it has not been presented here in these study results.

The Participatory Rural Appraisal at the study sites through various tools could highlight the available energy resources, felt need of the villagers, prioritize their perceptions and bring out the reality of the issues involved in various energy uses in the village ecosystem (Figure 9). PRA results provide very useful insights with energy balance estimates for policy relevant recommendations for Energy Sustainable Rural India.
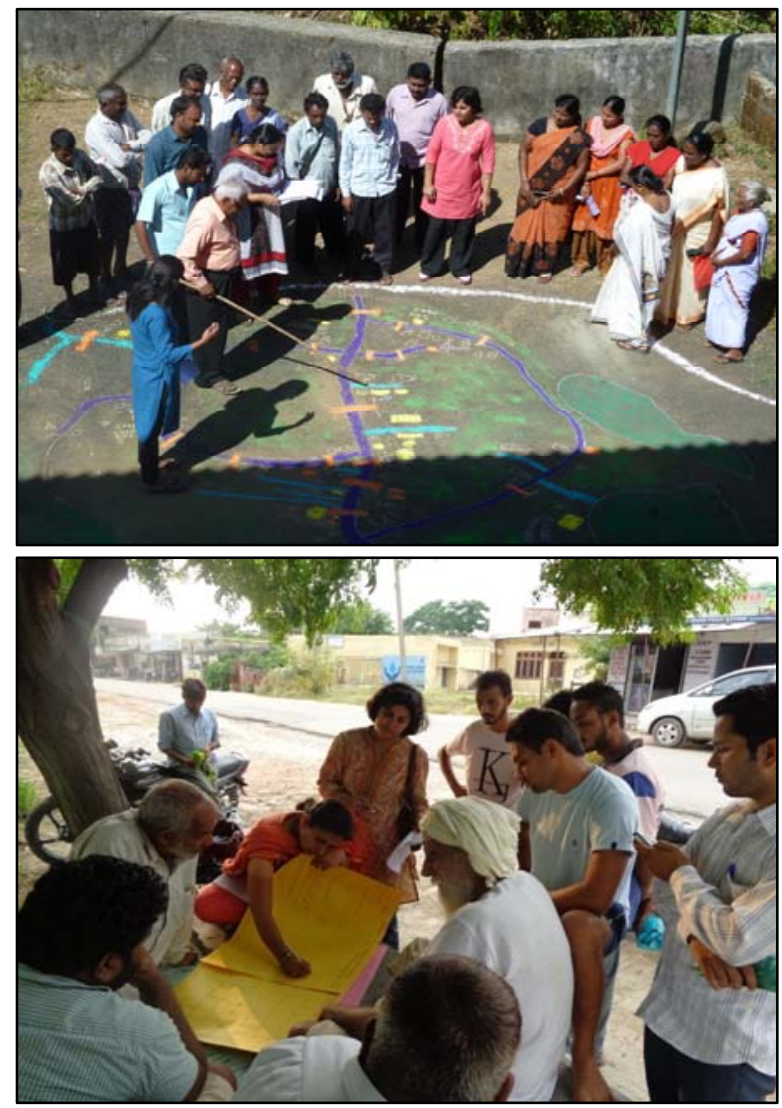

Figure 9: Participatory Rural Appraisal at Keralapuram, Andamans (top) and Macchiwara Kham, Punjab (bottom)

A comprehensive geotagged database of sampled households and available resources at each study site developed in ArcGIS framework provides detailed information on sampled households, surveyed resources with field photographs (Figure 10). The MS Access database of Rural Energy balance model may be later integrated with Village GIS framework in ArcGIS.
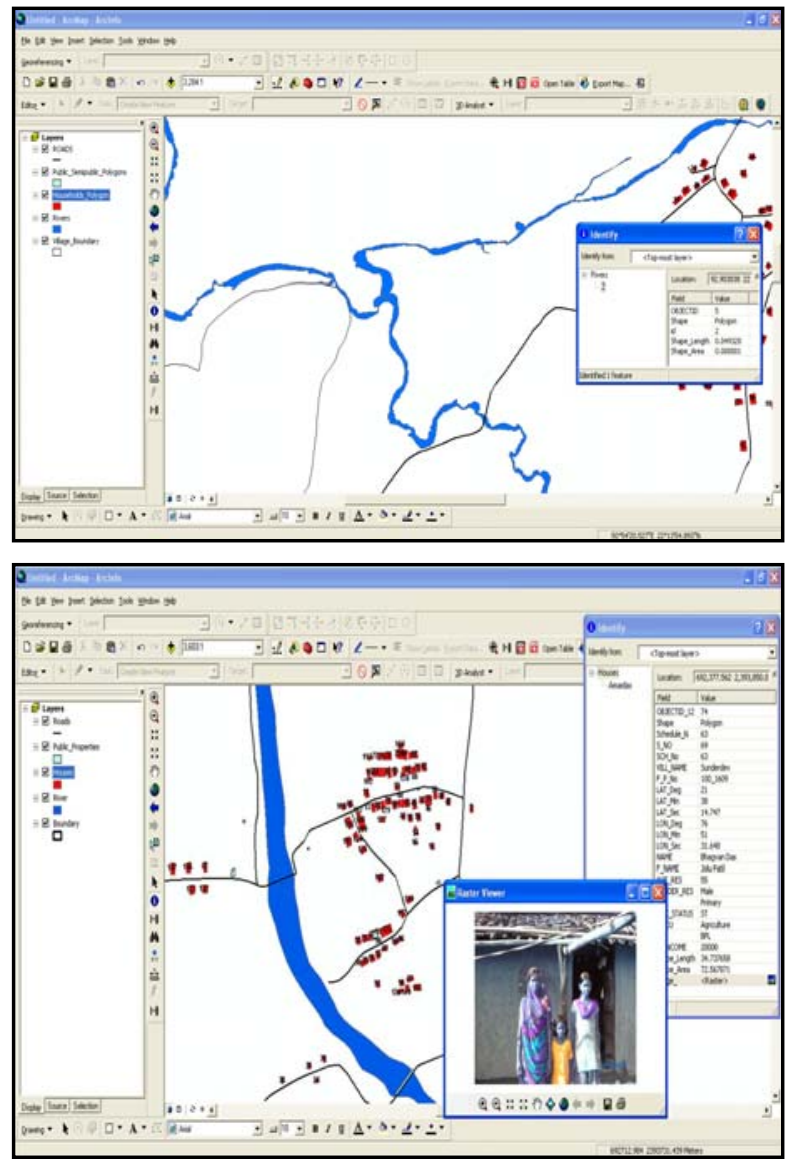

Figure 10: Village GIS developed for study sites

CONCLUSION

The study quantifies the pathways of anthropogenic energy flows in varied Rural Ecosystems in different agroclimatic regions of India. Seven sites located in different agroclimatic regions ranging from Trans Gangetic Plain Region in North to Islands Region in South, Gujarat Plains and Hills Region in West to Eastern Himalayan Region in East were studied. The study sites vary in geographical area, location, size, human and livestock population, availability of resources, agricultural practices, tree plantations etc. An End use energy accounting 'Rural Energy Balance Model' has been developed on MSAccess platform to provide a complete assessment of Net Energy Balance of a Rural Ecosystem. An integrated approach using field, ancillary, GIS and high resolution multi-temporal IRS-P6 Resourcesat-2 LISS IV data was developed for generation of various model inputs. The primary and secondary field data collection of various energy uses at household and village level were carried out using structured schedules and questionnaires. High resolution multi-temporal Resourcesat-2 LISS IV data (2013-14) was used for generating landuse/landcover classified maps and area under different classes and estimation of above-ground Trees Outside Forests phytomass. The study results show a positive energy balance for Ralegan Siddhi, Macchiwara Kham, Sunderdev, Keralapuram and Kollparru study sites, thus indicating an Energy Sustainable system. However, negative energy balance was estimated for Hodka and Phura villages indicating higher energy consumption as compared to energy production at village level. Across the study sites, the estimated net energy 
balance ranged from -18.8 Terra Joules (TJ) in a high energy consuming Hodka village, Gujarat to $224.7 \mathrm{TJ}$ in an agriculture, aquaculture and plantation intensive Kollaparru village of coastal Andhra Pradesh. The results indicate that the net energy balance of a Rural Ecosystem is largely driven by primary production through crops and natural vegetation. The use of solar energy as an alternative to fossil-fuel energy sources and production of energy through crops and natural vegetation is a viable option for transforming into energy sustainable villages. PRA conducted at each study site could highlight these priorities and available resources. In future, remote sensing based inputs like available solar radiation, vegetation fraction etc. would be integrated in the model. The Rural Energy balance model with its ability to handle large volume of data would serve as a very useful tool for estimation of net energy balance of Rural Ecosystems across the country. The detailed estimates of energy balance at each subsystem level of crop, livestock, tree plantation, rural livelihood, and industry in conjunction with results of Participatory Rural Appraisal at study sites provide a significant insight to policy relevant recommendations for Energy Sustainable Rural India.

\section{ACKNOWLEDGEMENTS}

This study has been carried out as a part of 'Energy and Mass Exchange in Vegetative Systems' project of ISRO Geosphere Biosphere programme. Authors are thankful to Shri A.S. Kiran Kumar, Director SAC for his constant encouragement and support to the study. Abha Chhabra wish to express sincere thanks to Dr. Prakash Chauhan, Group Head, Biological \& Planetary Sciences and Applications Group, EPSA/SAC and Dr. R.P. Singh, Head, Environment and Hydrology Division, BPSG/EPSA/SAC for their suggestions and guidance during the course of this study. The team of Project consultant, Research associates, Project associates and field investigators at CGARD-NIRD, and IIMA are thankfully acknowledged for their kind support and efforts during the course of this study. We also express sincere thanks to administrative staff and officials at district, block and village level for providing data and other necessary support for the purpose of this study.

\section{REFERENCES}

Agriculture Statistics 2013, Ministry of Agriculture, Government of India.

Basic Animal Husbandary, Statistics, 2013, Ministry of Agriculture, Govt. of India.

Brown, S.L, Schroeder, P., Kern, J.S., 1999. Spatial distribution of biomass in forests of Eastern USA. Forest Ecology and Management, 123, pp. 81-90.

\section{Census (2011) http://www.censusindia.gov.in}

Chandra, A., Pardha Saradhi, P., Rao, K.S., Saxena, K.G., Maikhuri, R.K., 2011. An investigation into the energy use in relation to yield of traditional crops in Central Himalaya, India. Biomass and Bioenergy, 35, pp. 2044-2052.

Dadhwal, V.K., Shah, A.K., Vora, A.B., 1994. Carbon flow through Indian agro ecosystem. A Preliminary account. In:
Global Change Studies-Scientific results from ISRO-GBP, ISRO, Dept. of Space, Govt. of India, pp. 203-226.

Dadhwal V.K, Shah A. K, Vora A.B., 1996. Changes in carbon flow through Indian agroecosystem between 1950-51 and 198586. Journal of Environ. Biology, 17(4), pp. 311-316.

FRI, 1996. Volume equations for forester of India, Nepal and Bhutan. Forest Research Institute, Dehradun, Ministry of Environment and Forests, Government of India.

Garg, A., Sharma, A., Nag, T., 2014. Energy Conversion Tables, 58p.

Hippel, D.F. Von, 2001. Rural Energy Survey in Unhari Village, The Democratic People's Republic Of Korea: Methods, Results, and Implications. Nautilus Institute for Security and Sustainable Development, USA, 66p.

Nag, T.., Garg, A., Sharma, A., Jacob, A., 2014. Rural Energy Balance Model. Access Model: User Manual, 40p.

NS0 Report No.540, 2010. Nutritional Intake in India.

Ozkan, B., Akcaoz, H., Fert, C., 2004. Energy input-output analysis in Turkish agriculture. Renewable Energy, 29: 39-51.

Pandya, M.R., Pathak, V.N., Shah, D.B., Chipade, R.A. and Singh, R.P., 2013. SACRS2: A scheme for atmospheric correction of Resourcesat-2 AWiFS data. SAC/EPSA/ABHG/EHD/SACRS2/SN/02/2013.

Pandya, S.M and Pedhadiya, M.D., 1993. Energy analysis of an Indian village semi-arid Ecosystem. Agriculture, Ecosystems and Environment, 45, pp. 157-175.

Patel, Y.P., Dabgar, Y.B., Joshi, P.N., 2012. Distribution and Diversity of Grass Species in Banni Grassland, Kachchh District, Gujarat, India. International Journal of Scientific Research and Reviews, 1(1), pp. 43-56.

Rawat, J. K., Dasgupta, S., Kumar, R., Kumar, A., Chauhan, K. V. S., 2005. Training manual on inventory of trees outside forests (TOF); Forest Survey of India (FSI), India.

Ramachandra T.V., Hegde, G., Setturu, B., Krishnadas, G., 2014. Bioenergy: A sustainable energy option for India. Advances in Forestry Letters, 3 (1), pp. 1-15.

Ramachandra, T.V., Subramanian, D.K., Joshi, N.V., Gunaga, S.V., Harikantra, S.B., 2000. Domestic energy consumption patterns in Uttara Kannada District, Karnataka State, India. Energy Conversion \& Management, 41, pp. 75-831.

Singh, A., Chakraborty, S., Roy, T. K., 2008. Village size in India. Asian Population Studies, 4(2), pp. 111-134.

Singh, K. and Chand, P., 2012. Above-ground tree outside forest phytomass and carbon estimation in the semi-arid region of southern Haryana: A synthesis approach of remote sensing and field data. Journal of Earth System Science, 121(6), pp. 1469-1482.

Sundarapandian, S.M., Amritha, S., Gowsalya, L., Kayathri, P., Thamizharasi, M., Dar, J.A., Srinivas K., Gandhi, S., 2013. Estimation of biomass and carbon Stock of woody plants in different land-uses. Forest Research, 3(1): 1-5. 